\title{
25. RADIOLARIANS OF THE CELEBES SEA, LEG 124, SITES 767 AND 7701
}

\author{
Reed P. Scherer ${ }^{2}$
}

\begin{abstract}
Two sites were drilled in the Celebes Sea as part of Ocean Drilling Program Leg 124; Site 767 and Site 770. Radiolarians are preserved in Paleogene pelagic claystones with minor occurrences in certain Neogene successions. The brown clays that immediately overlie basalt at both sites contain radiolarians of the late middle Eocene Podocyrtis chalara Zone. Late Eocene radiolarians are not found, due to dissolution and probable hiatus. The Oligocene is represented by the Theocyrtis tuberosa and Dorcadospyris ateuchus Zones. Oligocene sediments are strongly dominated by abundant and diverse radiolarians of the Tristylospyris/Dorcadospyris lineage. Preservation of Paleogene radiolarian assemblages ranges from good to very poor. Late Miocene radiolarians of the Didymocyrtis antepenultima Zone are found only in Site 770 . Other Neogene sediments are barren of radiolarian remains, with the exception of latest Pleistocene and Holocene sediments.
\end{abstract}

\section{INTRODUCTION}

The Celebes Sea is a partially enclosed marginal basin of the western equatorial Pacific, which is bound to the west by Borneo, to the north by the Sulu Archipelago, to the south by Sulawesi, and to the east by Mindanao and the Sangihe arc. Two sites were drilled in the northeastern part of the Celebes Basin as part of ODP Leg 124 (Fig. 1). Sediments at Site 767 $\left(4^{\circ} 47.5^{\prime} \mathrm{N}, 123^{\circ} 30.2^{\prime} \mathrm{E} ; 4906 \mathrm{~m}\right.$ water depth) include nearly 700 $\mathrm{m}$ of volcanogenic and hemipelagic clay and clayey silt with abundant carbonate and volcanic ash turbidites. Terrigenous turbidite influx reached a peak during the middle Miocene. Underneath the continentally influenced sediments, $88 \mathrm{~m}$ of middle Eocene through late Oligocene pelagic brown clays were recovered. These claystones overlie basalt.

Site $770\left(5^{\circ} 8.7^{\prime} \mathrm{N}, 123^{\circ} 40.1^{\prime} \mathrm{E} ; 4505 \mathrm{~m}\right.$ of water) is on an upthrown fault block, $23 \mathrm{nmi}(43 \mathrm{~km})$ north-northeast of Site 767. The upper $340 \mathrm{~m}$ of sediment was spot-cored at an interval of $50 \mathrm{~m}$. Sediments at Site 770 include green hemipelagic clays and ashes and underlain middle Eocene through late Oligocene brown clays and marls. The total sediment column at Site 767 is $787 \mathrm{~m}$ thick, whereas Site 770 has only $423 \mathrm{~m}$ of sediment, due to the reduced contribution of turbidites in the shallower site.

With the exception of the Holocene to Pleistocene muds, radiolarians are very rare or absent in the turbidite sequences of Site 767 , due to silica dissolution and dilution by terrigenous and volcanogenic debris. Sedimentation rates were slower through the Neogene at Site 770, and well-preserved radiolarians are found in one core of green hemipelagic clays that was recovered by spot coring. Brown clays and marls near the base of the sedimentary successions at both sites include variable concentrations of radiolarians, with preservation ranging from good to barely recognizable and barren.

\section{METHODS}

Standard radiolarian preparation methods were used for processing and evaluating Celebes Sea sediments collected during ODP Leg 124. Samples were sieved with both $63-\mu \mathrm{m}$

\footnotetext{
${ }^{1}$ Silver, E. A., Rangin, C., von Breymann, M. T., et al., 1991. Proc. ODP, Sci. Results, 124: College Station, TX (Ocean Drilling Program).

2 Department of Geological Sciences, The Ohio State University, Columbus, OH, 43210 U.S.A.
}

and $44-\mu \mathrm{m}$ mesh screens. The fraction $>44 \mu \mathrm{m}$ was particularly useful in evaluating relative abundances of smaller radiolarians and those more susceptible to breakage. Multiple slides of each sample were examined.

Abundance of radiolarians in the fraction $>63 \mu \mathrm{m}$ as shown on the range charts (Tables 1 and 2) is according to the chart below. Abundance estimates are qualitative, determined by the visual approximation of the total amount of residue per 10 $\mathrm{cm}^{3}$ of sediment and of the percentage of radiolarian specimens observed in this residue. Turbidites, ash-rich layers, and samples rich in authigenic minerals often left volumes of residues greater than those indicated in the relative abundance scheme described below.

A (abundant) $=1 \mathrm{~cm}^{3}$ of residue, $>80 \%$ radiolarians.

$\mathrm{C}$ (common) $=\sim 0.1-1 \mathrm{~cm}^{3}$ of residue, $10 \%-80 \%$ radiolarians.

$\mathrm{F}$ (few) $=\sim 0.1-1 \mathrm{~cm}^{3}$ of residue, $1 \%-10 \%$ radiolarians.

$\mathrm{R}($ rare $)=\sim 0.1-1 \mathrm{~cm}^{3}$ of residue; more when rich in allochthonous or authigenic minerals, percentage of radiolarians.

$\mathrm{T}($ Trace $)=1-10$ radiolarians or radiolarian fragments seen on at least one entire slide.

B $($ barren $)=$ no radiolarians or radiolarian fragments seen on at least one entire slide.

Abundance counts of individual radiolarian taxa noted on range charts (Tables 1 and 2) are based on visual estimates in the microscope at $100 \times$ magnification (10× objective). Specific abundances are as noted:

A (abundant) $=$ at least one specimen seen in each field of view. $\mathrm{C}($ common $)=$ at least one specimen seen in five fields of view.

$\mathrm{F}(\mathrm{few})=$ at least one specimen seen per transect.

$\mathrm{R}(\mathrm{rare})=$ fewer than ten specimens per slide.

$\mathrm{T}$ (trace) $=$ single specimen and/or only fragments seen in one or more slides.

Radiolarian preservation ranges from good to very poor. Degraded preservation is a result of dissolution or etching of the siliceous skeleton, recrystallization of opaline silica, or replacement by zeolites or other minerals.

Preservation as shown on range charts (Tables 1 and 2) is defined as follows:

$\mathrm{G}=$ Good: Most specimens are complete with spines mostly preserved, little or no etching or mineral overgrowths are 


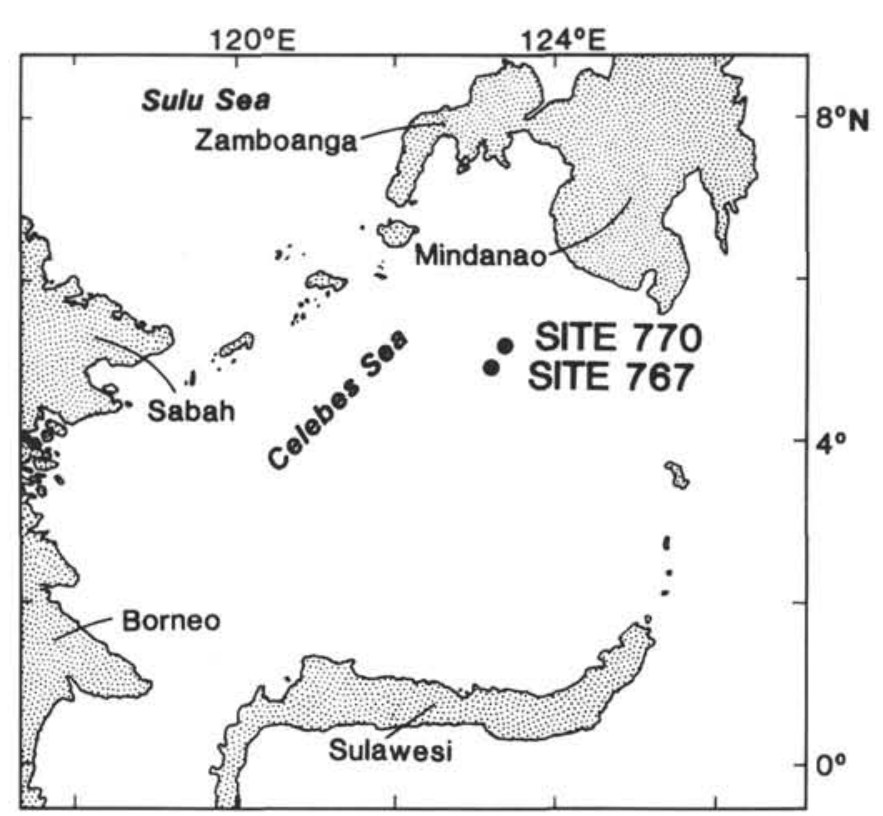

Figure 1. Location of Sites 767 and 770 in the Celebes Sea.

present; cement or clay matrix may fill cavities, but the outer surface is intact. Nearly all specimens are identifiable.

$\mathbf{M}=$ Moderate: A substantial portion of the specimens are broken, and some degree of overgrowth, etching, or replacement or recrystallization may be evident. About half of the specimens can be identified.

$\mathbf{P}=$ Poor: Specimens are mostly broken and strongly etched or replaced. Only about $5 \%$ of the specimens can be reliably identified.

VP = Very poor: Specimens are strongly etched or encrusted. Positive identification is impossible for nearly every specimen; however, tentative identification is possible with distinctive taxa.

Taxonomic treatment of radiolarians in this work is not exhaustive. This is due largely to the poor preservation of the radiolarian assemblages in much of the sediment recovered during Leg 124 in the Celebes Sea. Radiolarian assemblages were assigned to biozones initially proposed by Riedel and Sanfilippo $(1970,1971,1978)$ and later revised by Sanfilippo et al. (1985). Radiolarian zones are determined from range charts (Tables 1 and 2).

\section{RADIOLARIAN-BASED BIOSTRATIGRAPHY OF THE CELEBES SEA}

\section{Site 767}

Three holes were drilled at Site 767 in the Celebes Sea. One core, of Holocene to Pleistocene age, was taken in Hole 767A. Hole 767B was drilled to a total depth of $739.0 \mathrm{mbsf}$. Hole $767 \mathrm{C}$ was washed down to $680.0 \mathrm{mbsf}$ and then cored to 794.7 mbsf. The sedimentary sequence ranges in age from Pleistocene to upper middle Eocene. Eocene sediment overlies basaltic basement, which was encountered in Section 124767C-12R, CC at 786.6 mbsf. With the exception of radiolarians in latest Pleistocene and Holocene sediments, and rare occurrences of radiolarian fragments in turbidites, radiolarians are present only in reddish brown claystones that underlay the thick Miocene and younger successions of hemipelagic clays, turbidites, and ash-fall deposits.

The transition from grayish green hemipelagic to underlying reddish brown pelagic claystones occurs in Section 124-
767B-74X-3, at 698 mbsf. Radiolarians are present in the claystones below Section 124-767B-76X-5 (723 mbsf), after 25 $\mathrm{m}$ of brown pelagic clay that is barren of radiolarians. The only fossils present in the upper part of the brown clay unit include ichthyoliths and arenaceous foraminifers. Several intervals that are barren of radiolarians contain abundant sand-sized grains of authigenic manganese carbonate (rhodochrosite) (Table 1).

Radiolarians are abundant but poorly preserved in Sample 124-767B-76X-6, 4-6 cm (720.8 mbsf). The dominant forms are of the genus Dorcadospyris. Specimens are badly corroded, and the feet are missing from every specimen. Dorcadospyris ateuchus is tentatively identified based on the presence and orientation of the "stumps" where feet were attached, and the shape and size of the lattice shell; however, few of the spyrids present can be reliably identified to the species level. Dorcadospyris simplex and other spyrids, including forms resembling Trystylospyris triceros, the ancestor of the Dorcadospyris lineage, are present in this assemblage.

Also present in Sample 124-767B-76X-6, 4-6 cm are rare Lithocyclia angusta, Theocyrtis annosa, Cyclampterium pegetrum, and Atrophormis gracilis among others. Most specimens of Lithocyclia angusta in this interval have rather triangular cortical shells, three arms that fuse to a solid spine, and have a fairly regular orientation of pores on the cortical shell (Pl. 2, Fig. 7). This morphotype is typical of $L$. angusta late in its range (Sanfilippo et al., 1985). Also present is a radiolarian that may be related to Lychnocanoma trifolium, which in this report is referred to as Lychnocanoma sp. A (PI. 1, Figs. 6-8; see systematic section for discussion of this taxon). The radiolarian assemblage identified represents the middle to lower part of the Dorcadospyris ateuchus Zone, early late Oligocene in age. This assemblage is found down to about 736 mbsf (Sample 124-767C-6R, CC).

A change in the radiolarian assemblage is noted in the last core taken in Hole 767B. Only $1.3 \mathrm{~m}$ of sediment was recovered in Core 124-767B-78X. Samples from the upper part of the core (733 mbsf) contain $T$. annosa and a dominance of Dorcadospyris species that resemble D. ateuchus, suggesting the $D$. ateuchus Zone. However, the core catcher of 124767B-78X (739 mbsf) contains Theocyrtis tuberosa (Pl. 2, Fig. 4) and common spyrids that resemble the ancestor of the Dorcadospyris lineage, Tristylospyris triceros. This assemblage represents the lowermost $D$. ateuchus Zone or the upper part of the $T$. tuberosa Zone, early Oligocene in age.

The unrecovered interval that includes the transition from $D$. ateuchus Zone to $T$. tuberosa Zone in Core 127-767B-78X was recovered in Hole 767C, in Core 124-767C-7R (735.8$743.3 \mathrm{mbsf}$ ). Samples from this core are nearly barren of radiolarians, and samples from the upper part contain common rhodochrosite grains. A relatively brief hiatus may be present in this barren interval. In Core 124-767C-8R, between Section 1 and the core catcher, preservation is very poor and many samples are barren, thus little radiolarian age control is possible in this interval. Sample $124-767 C-8 R-2,99-101 \mathrm{~cm}$, is barren of radiolarians and contains abundant manganese micronodules (up to $5 \mathrm{~mm}$ in diameter), indicating a period of erosion or nondeposition. Identifiable, though poorly preserved, radiolarians are found in the core catcher of Core 124-767C-8R. Sample 124-767C-9R-1, 90-92 cm, contains abundant radiolarians of the $T$. tuberosa Zone, although other samples in this interval are barren.

No sediment was recovered in Core 124-767C-10R and Core $124-767 \mathrm{C}-11 \mathrm{R}$ recovered only $2.6 \mathrm{~m}$, with no recovery in the core catcher. Sample 124-767C-11R-2, 104-106 cm, contains very few radiolarians, but rare specimens of $T$. triceros and $T$. tuberosa have been found, demonstrating that this 
Table 1. Occurrences of radiolarians and interpreted radiolarian zonal assignments for Holes 767B and 767C. Abundance and preservation codes are defined in the text.

\begin{tabular}{|c|c|c|c|c|c|c|c|c|c|c|c|c|c|c|c|c|c|c|c|c|c|c|c|c|c|c|c|}
\hline $\begin{array}{l}\text { Hole, core, section, } \\
\text { interval }(\mathrm{cm})\end{array}$ & 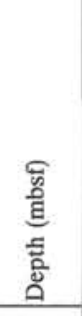 & 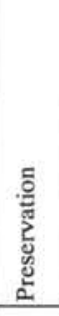 & 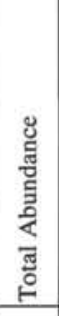 & 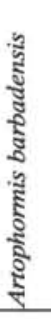 & 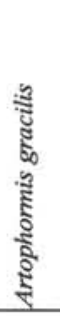 & 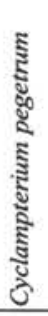 & 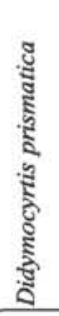 & 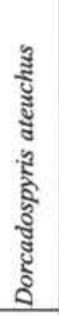 & 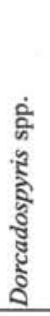 & 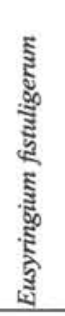 & 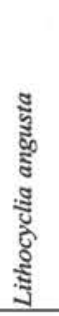 & 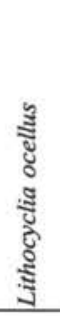 & 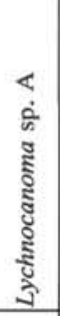 & 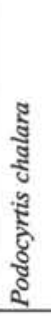 & 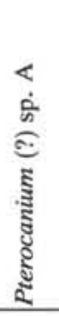 & 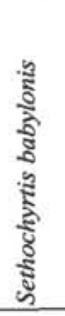 & 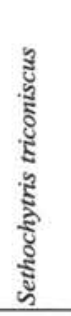 & 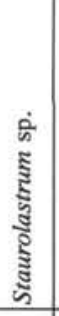 & 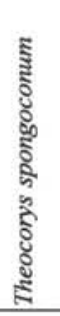 & 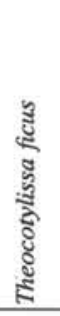 & 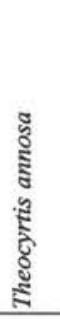 & 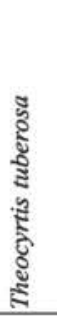 & 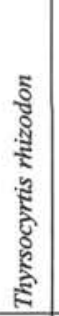 & 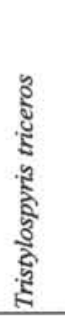 & 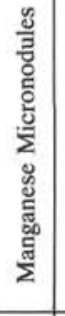 & 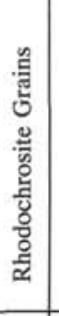 & Radiolarian Zone \\
\hline 124. & & & & & & & & & & & & & & & & & & & & & & & & & & & \\
\hline $\begin{array}{l}\text { 767B-73X, CC } \\
\text { 767B-74X-5, 54-56 }\end{array}$ & 694.6 & - & B & & & & & & & & & & & & & & & & & & & & & & & & \\
\hline $\begin{array}{l}\text { 767B-74X-5, 54-56 } \\
\text { 767B-74X, CC }\end{array}$ & $\begin{array}{l}701.1 \\
704.2\end{array}$ & $\overline{-}$ & $\begin{array}{l}\mathrm{B} \\
\mathrm{B}\end{array}$ & & & & & & & & & & & & & & & & & & & & & & & & \\
\hline $767 \mathrm{~B}-75 \mathrm{X}-5,47-49$ & 710.7 & - & B & & & & & & & & & & & & & & & & & & & & & & & A & \\
\hline $767 \mathrm{C}-4 \mathrm{R}, \mathrm{CC}$ & 716.5 & - & B & & & & & & & & & & & & & & & & & & & & & & & & \\
\hline $767 \mathrm{C}-5 \mathrm{R}-1,59-62$ & 717.1 & - & B & & & & & & & & & & & & & & & & & & & & & & & C & barren \\
\hline 767B-76X-3, 126-8 & 717.5 & - & B & & & & & & & & & & & & & & & & & & & & & & & & \\
\hline 767B-76X-4, 4-7 & 717.8 & - & B & & & & & & & & & & & & & & & & & & & & & & & & \\
\hline 767B-76X-4, 50-54 & 718.2 & - & B & & & & & & & & & & & & & & & & & & & & & & & & \\
\hline 767B-76X-5, 41-44 & 719.9 & - & B & & & & & & & & & & & & & & & & & & & & & & & & \\
\hline $767 C-5 R-3,56-59$ & 720.1 & - & B & & & & & & & & & & & & & & & & & & & & & & & & \\
\hline $767 \mathrm{~B}-76 \mathrm{X}-6,4-6$ & 721.0 & $\mathrm{P}$ & A & & $\mathbf{R}$ & C & & C & A & & $\mathrm{R}$ & & $\mathrm{R}$ & & & & & & $\mathbf{R}$ & & & & & $\mathbf{R}$ & & & (n........ \\
\hline 767B-76X-7, 38-41 & 722.9 & $\mathrm{P}$ & C & & $\mathbf{R}$ & $\mathrm{F}$ & & C & A & & $\mathrm{R}$ & & $\mathrm{F}$ & & & & & & & & & & & $\mathbf{R}$ & & & \\
\hline $767 \mathrm{~B}-77 \mathrm{X}-2,23-26$ & 725.0 & $\mathbf{P}$ & C & & $\mathbf{R}$ & $\mathrm{F}$ & & $\mathrm{F}$ & A & & $\mathbf{R}$ & & $\mathbf{R}$ & & & & & $\mathbf{R}$ & & & $\mathrm{F}$ & & & & & & \\
\hline $767 \mathrm{C}-5 \mathrm{R}, \mathrm{CC}$ & 726.2 & - & B & & & & & & & & & & & & & & & & & & & & & & & $\mathrm{F}$ & \\
\hline $767 C-6 R-3,31-34$ & 729.5 & - & B & & & & & & & & & & & & & & & & & & & & & & & & \\
\hline 767B-77X, CC & 732.9 & P & C & & F & $\mathrm{F}$ & $\mathrm{R}$ & $\mathrm{F}$ & A & & C & & $\mathrm{F}$ & & $\mathrm{F}$ & & & $\mathbf{R}$ & & & $\mathbf{F}$ & & & $\mathbf{R}$ & & & \\
\hline 767B-78X-1, 54-57 & 733.5 & $\mathbf{P}$ & A & & F & $\mathrm{F}$ & $\mathbf{R}$ & C & A & & C & & $\mathrm{F}$ & & $\mathrm{F}$ & & & $\mathbf{R}$ & $\mathbf{R}$ & & $\mathbf{R}$ & & & $\mathbf{R}$ & & & D. ateuchus zone \\
\hline 767B-78X-1, $90-93$ & 733.8 & $\mathbf{P}$ & F & & $\mathrm{F}$ & $\mathbf{R}$ & & $\mathrm{F}$ & A & & $\mathrm{F}$ & & $\mathrm{F}$ & & & & & & & & $\mathrm{F}$ & & & $\mathrm{R}$ & & & D. usenctios zoric \\
\hline $767 \mathrm{C}-6 \mathrm{R}-5,39-42$ & 734.1 & $\mathbf{P}$ & C & & $\mathrm{F}$ & $\mathbf{R}$ & $\mathbf{R}$ & & A & & $\mathrm{F}$ & & $\mathrm{F}$ & & & & & $\mathrm{R}$ & & & $\mathrm{F}$ & & & $\mathrm{C}$ & & & \\
\hline $767 \mathrm{C}-6 \mathrm{R}-6,59-62$ & 734.3 & P & $\mathrm{R}$ & & $\mathrm{R}$ & $\mathbf{R}$ & & F & C & & $\mathrm{F}$ & & & & $\mathrm{R}$ & & & & & & & & & $\mathrm{R}$ & & & \\
\hline 767C-6R, CC & 735.8 & $\mathrm{P}$ & $\mathrm{F}$ & & $\mathrm{R}$ & $\mathrm{F}$ & & $\mathrm{F}$ & C & & F & & & & & & & $\mathrm{R}$ & & & $\mathrm{F}$ & & & $\mathrm{R}$ & & C & \\
\hline $767 \mathrm{C}-7 \mathrm{R} 1,11-13$ & 735.9 & - & B & & & & & & & & & & & & & & & & & & & & & & & C & \\
\hline $767 \mathrm{C}-7 \mathrm{R}-2,4-6$ & 737.4 & - & B & & & & & & & & & & & & & & & & & & & & & & & C & \\
\hline $767 \mathrm{C}-7 \mathrm{R}-2,46-49$ & 737.8 & VP & $\mathrm{T}$ & & & & & & & & & & & & & & & & & & & & & & & & \\
\hline 767B-78X, CC & 739.0 & $P$ & $\mathrm{R}$ & & F & $\mathrm{F}$ & $\mathbf{R}$ & C & A & & $\mathrm{F}$ & & $\mathbf{R}$ & & & & & $\mathrm{F}$ & & & & C & & C & & & \\
\hline $767 \mathrm{C}-7 \mathrm{R}, \mathrm{CC}$ & 743.3 & VP & $\mathrm{T}$ & & & & & & & & & & & & & & & & & & & & & & & & \\
\hline $767 \mathrm{C}-8 \mathrm{R}-1,15-17$ & 743.5 & P & C & & $\mathrm{R}$ & $\mathrm{F}$ & $\mathbf{R}$ & $\mathbf{R}$ & A & & $\mathrm{R}$ & & $\mathrm{F}$ & & $\mathrm{F}$ & & & & & & & F & & $\mathrm{C}$ & & & \\
\hline $767 \mathrm{C}-8 \mathrm{R}-2,4-6$ & 744.9 & VP & C & & & $?$ & & & $?$ & & ? & & & & & & & & & & & & & & & & \\
\hline $767 \mathrm{C}-8 \mathrm{R}-2,50-52$ & 745.3 & $\mathrm{P}$ & $\mathbf{R}$ & & & & & & & & & & & & & & & & & & & & & & & & \\
\hline $767 \mathrm{C}-8 \mathrm{R}-2,99-101$ & 745.8 & - & B & & & & & & & & & & & & & & & & & & & & & & A & & \\
\hline 767C-8R-2, $113-15$ & 745.9 & VP & C & & & $?$ & & & $?$ & & $?$ & & & & & & & & & & & & & & & & T. tuberosa zone \\
\hline $\begin{array}{l}\text { 767C-8R-3, } 26-28 \\
767 \mathrm{C}-8 \mathrm{R}-3,69-72\end{array}$ & $\begin{array}{l}746.6 \\
747.0\end{array}$ & - & $\begin{array}{l}\text { B } \\
\text { B }\end{array}$ & & & & & & & & & & & & & & & & & & & & & & & & 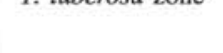 \\
\hline $767 \mathrm{C}-8 \mathrm{R}, \mathrm{CC}$ & 753.0 & $\mathbf{P}$ & $\mathbf{F}$ & & $\mathrm{F}$ & & & & C & & $\mathbf{R}$ & & & & $\mathrm{R}$ & & & $\mathbf{R}$ & & & & F & & C & & & \\
\hline $767 \mathrm{C}-9 \mathrm{R}-1,64-67$ & 753.7 & - & B & & & & & & & & & & & & & & & & & & & & & & & & \\
\hline $767 \mathrm{C}-9 \mathrm{R}-1,90-92$ & 753.9 & $\mathbf{P}$ & A & & F & $\mathrm{F}$ & & & C & & C & & & & $\mathrm{F}$ & & & $\mathbf{R}$ & & & & C & & $\mathrm{F}$ & & & \\
\hline 767C-9R, CC & 762.7 & P & $\mathbf{R}$ & & & $\mathrm{R}$ & & & F & & $\mathrm{R}$ & & & & & & & & & & & & & $\mathrm{F}$ & & & \\
\hline $767 \mathrm{C}-11 \mathrm{R}-1,30-32$ & 772.7 & - & B & & & & & & & & & & & & & & & & & & & & & & & & \\
\hline $767 \mathrm{C}-11 \mathrm{R}-2,104-6$ & 776.0 & $\mathbf{P}$ & $\mathbf{R}$ & & & & & & $\mathbf{R}$ & & & & & & & & & & & & & $\mathrm{R}$ & & $\mathbf{R}$ & & & \\
\hline $767 \mathrm{C}-12 \mathrm{R}-1,38-40$ & 782.5 & VP & A & $?$ & & & & & & $?$ & & ? & & $?$ & & & $?$ & & & ? & & & $?$ & & & & hiatus - \\
\hline $767 \mathrm{C}-12 \mathrm{R}-1,60-62$ & 782.7 & VP & A & & & & & & & ? & & $?$ & & $?$ & & & ? & & & & & & ? & & & & \\
\hline $767 \mathrm{C}-12 \mathrm{R}-2,35-37$ & 784.0 & VP & A & $?$ & & & & & & & & $?$ & & & & $?$ & $?$ & & & & & & & & & & \\
\hline $767 \mathrm{C}-12 \mathrm{R}-3,20-22$ & 786.1 & VP & C & & & & & & & ? & & $?$ & & & & & $?$ & & & $?$ & & & $?$ & & & & $P$. chalara zone \\
\hline $767 \mathrm{C}-12 \mathrm{R}-3,121-3$ & 786.3 & VP & $\mathbf{R}$ & & & & & & & & & & & & & & & & & & & & & & & & \\
\hline $767 \mathrm{C}-12 \mathrm{R}-3,133-5$ & 786.4 & VP & $\mathrm{R}$ & & & & & & & & & & & & & & & & & & & & & & & & \\
\hline
\end{tabular}


Table 2. Occurrences of radiolarians and interpreted radiolarian and nannofossil (Shyu and Müller, this volume) zonal assignments for Holes 770B and 770C. Abundance and preservation codes are defined in the text.

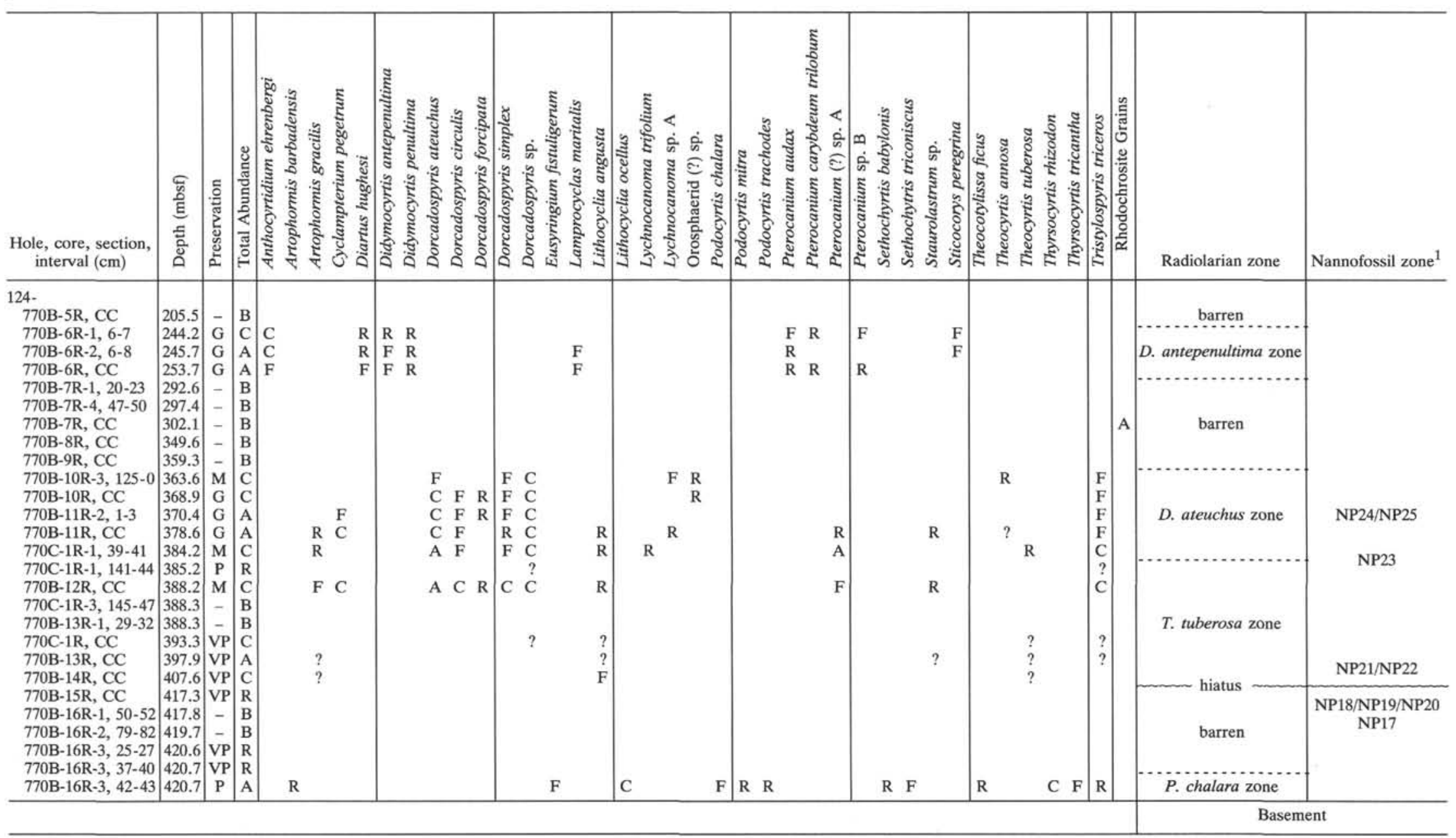

${ }^{1}$ Shyu and Müller, this volume 
sample is still early Oligocene in age. Below Sample 124-767C$11 \mathrm{R}-2,104-106 \mathrm{~cm}$, is an unrecovered gap of more than $6 \mathrm{~m}$. A major change in the radiolarian assemblage occurs somewhere in this gap.

Samples from Core 124-767C-12R, which ended in basalt, contain very abundant but extremely poorly preserved radiolarians. Preservation is too poor for positive identification of nearly all specimens. However, the high concentration of radiolarians in these samples allowed examination of great numbers of specimens, many of which could be tentatively identified as significant biostratigraphic markers. These include Lithocyclia ocellus, Sethochytris triconiscus (Pl. 4, Fig. 6), Theocotylissa ficus, Thyrsocyrtis rhizodon, Eusyringium fistuligerum, Podocyrtis chalara, and other middle Eocene forms that indicate the late middle Eocene $P$. chalara Zone. Radiolarian Zones Podocyrtis goetheana and Thyrsocyrtis bromia (= Calocyclas bandyca Zone, "Carpocanistrum" azyx Zone, and Cryptroprora ornata Zone of Saunders et al., 1985) are not represented. This suggests the presence of a hiatus spanning about $7 \mathrm{~m} . y$. in the $6-\mathrm{m}$ interval between Cores 124-767C-11R and 124-767C-12R.

Despite recrystallization and strong etching of the radiolarian specimens found in Core $124-767 \mathrm{C}-12 \mathrm{R}$, these samples contain the highest abundance of radiolarians found in all Leg 124 sediments, suggesting very high biogenic productivity during the late middle Eocene. Some radiolarian remains are found in the sediments directly overlying basaltic basement at 786.4 mbsf, but preservation is too poor for even tentative identification. The lowest dateable radiolarian assemblage recovered is from Sample 124-767C-12R-3, 20-23 $\mathrm{cm}$ (786.5 mbsf), about $4 \mathrm{~m}$ above basement. This constrains the age of basalt emplacement to late middle Eocene (42 Ma) or older.

\section{Site 770}

Three holes were drilled at Site 770 . The sedimentary sequence of $425 \mathrm{~m}$ thickness overlying basalt ranges in age from Pleistocene to upper middle Eocene, similar to Site 767. Radiolarians and diatoms are abundant in the uppermost sediments collected at Site 770 (Cores 124-770A-1R and 124-770B-1R) but degradation of these fossils is rapid in the first meter of sediment below seafloor. This pattern of siliceous microfossil degradation was noted at all Leg 124 sites that recovered mud-line cores. Spot-cored intervals from Section 124-770B-2R, CC (60.8 mbsf) through 124-770B-5R, CC (205.5 mbsf) are barren of radiolarians.

Well-preserved radiolarians are found in great abundance in spot-cored Core 124-770B-6R (244.1-253.7 mbsf). Radiolarians present include Didymocyrtis antepenultima, a late form of Sticocorys delmontensis, and early forms of Sticocorys peregrina, Phormostichoartus corbula, Pterocanium audax, and an early form of Pterocanium carybdium trilobum. Also present is a pterocaniid that is referred to here as Pterocanium sp. B (Pl. 1, Fig. 5). According to Lazarus et al. (1985), this radiolarian is probably related to $P$. audax. Many of the specimens of $D$. antepenultima closely resemble its descendent, Didymocyrtis penultima, suggesting that the assemblage may be near the top of the early late Miocene $D$. antepenultima Zone.

Spot-cored Core $124-770 \mathrm{~B}-7 \mathrm{R}$ ( 292.4 to $302.1 \mathrm{mbsf}$ ) is barren of radiolarians. In this core, lithology grades from greenish gray hemipelagic clays above Section 124-770B-7R-3 (296 mbsf) to grayish brown pelagic clay below. Sample 124-770B-7R, CC contains abundant rhodochrosite grains in brown clay. Continuous coring began in brown clay with Core 124-770B-8R (340 mbsf). Cores 124-770B-8R and 124$770 \mathrm{~B}-9 \mathrm{R}$ contain no radiolarian remains.
A generally well-preserved radiolarian assemblage is found in brown clays of Section 124-770B-10R-1 (359.3 mbsf) through $124-770 \mathrm{~B}-12 \mathrm{R}, \mathrm{CC}$ (388.2 mbsf). This assemblage is dominated by members of the radiolarian genus Dorcadospyris, which constitute more than $80 \%$ of the fauna in some samples. Samples from Cores 124-770B-10R and 124-770B$11 \mathrm{R}$ contain $D$. ateuchus, D. simplex, and others in the lineage, including abundant transitional and undescribed forms. Additionally, Sample 124-770B-10R-3, $125-130 \mathrm{~cm}$, contains Lychnocanoma sp. A. Lychnocanoma sp. A is rare, but preservation is better here than in samples from Site 767. Sample 124-770B-10R-3, 125-130 also contains abundant $Z y$ gocircus (Butschli) sp. This assemblage is of the D. ateuchus Zone, late Oligocene age.

Sample 124-770B-10R CC (369 mbsf) contains abundant and diverse Dorcadospyris species, including forms closely resembling the ancestor of this lineage, Tristylospyris triceros. However, the third, central appendage is generally somewhat less robust than the two primary feet in these specimens. $T$. annosa is very rare and Lychnocanoma $\mathrm{sp}$. A has not been found. Samples from Core 124-770B-11R are rich in wellpreserved radiolarians, including the diverse and abundant Dorcadospyris lineage. Additionally, Artophormis gracilis, Cyclampterium pegetrum, and Lithocyclia angusta are present. Rare fragments of a radiolarian that resembles $T$. annosa have been found in Sample 124-770B-11R, CC (378.6 mbsf), but other than this, neither $T$. annosa nor $T$. tuberosa have been found in this core. Rare examples of Lychnocanoma sp. $A$ are present in this sample as well. The base of Core 124-770B-12R (official depth, $388.2 \mathrm{mbsf}$ ) has the low-diversity Dorcadospyris assemblage with abundant transitional forms in the lineage. Theocyrtis species appear to be absent.

The top of Core 124-770B-13R (388.2 mbsf) marks a change in lithology from pelagic clay lacking appreciable carbonate (above) to a nannofossil marl (below). The contact between these lithologies was not recovered. Radiolarians are absent from this interval, but nannofossils show an early Oligocene age (Zone NP23; Shyu and Müller, this volume). In an attempt to recover this lithologic contact, one spot-core was taken at this level in Hole $770 \mathrm{C}$. Although the lithologic contact was not recovered in Core 124-770C-1R, some of the section that is missing from Hole $770 \mathrm{~B}$, between Cores $124-770 \mathrm{~B}-12 \mathrm{R}$ and 124-770B-13R, was recovered, providing additional stratigraphic information for this critical interval.

Samples from the upper part of Section 124-770C-1R contain early late Oligocene nannofossils (Zone NP24) and radiolarians (D. ateuchus Zone). Sample 124-770C-1R-1, $39-42 \mathrm{~cm}$ includes well-preserved $D$. ateuchus and others in the lineage, including rare Tristylospyris triceros (PI. 4, Fig. 2) and very rare Lychnocanoma trifolium (sensu stricto) $(\mathrm{Pl} .1$, Fig. 1). Theocyrtis tuberosa (Pl. 2, Figs. 5, 6) is present and $T$. annosa is absent. An unidentified theoperid, referred to as Pterocanium (?) sp. A (Pl. 1, Figs. 9-11) is abundant in this sample. The presence of $D$. ateuchus and $L$. trifolium indicate the $D$. ateuchus Zone, but the occurrence of Tristylospyris triceros and $T$. tuberosa might suggest the $T$. tuberosa Zone. Calcareous nannofossils identify the top of nannofossil Zone NP23 in the lower part of this core (Sheu and Müller, this volume). Based on the above information, this sample reflects the lower part of the D. ateuchus Zone. Below the level of this sample in Core 124-770C-1R, radiolarians are absent or too poorly preserved for accurate radiolarian biostratigraphic zoning, though calcareous nannofossils are present and provide relatively good age control.

Sample 124-770C-1R, CC contains common but very poorly preserved radiolarians. $T$. triceros and $T$. tuberosa are identified, suggesting the $T$. tuberosa Zone of the early Oli- 
gocene, which is in agreement with nannofossils (Zone NP 23; Sheu and Müller, this volume). A similar, also very poorly preserved, radiolarian assemblage is found in Cores 124-770B13R and 124-770B-14R. This assemblage includes $T$. tuberosa, $T$. triceros, A. gracilis, and $L$. angusta. Specimens of $L$. angusta are most commonly the morphotype typical of this radiolarian in the earlier part of its range (i.e., round, spongy cortical shell and long, spongy arms) (Pl. 2, Fig. 9).

Rare radiolarians found in Core 124-770B-15R and most of the sedimentary section of Core 124-770B-16R are too poorly preserved for identification, with one notable exception. Sediments immediately overlying a thin hyaloclastite unit (Sample 124-770B-16R-3, $43 \mathrm{~cm}),{ }^{3}$ about $22 \mathrm{~cm}$ above basalt, contain an abundant but poorly preserved radiolarian assemblage (Fig. 2). The fossils are completely recrystallized, but are readily identifiable. One $\mathrm{cm}$ above this level, radiolarian preservation is too poor for identification, and no radiolarians have been found within the hyaloclastites. This thin layer contains a diverse radiolarian assemblage that contains all taxa identified in Eocene sediments that overlie basement at Site 767. Much better preservation in this sample allows identification of many more late middle Eocene taxa than is possible with Site 767 samples. Some of the radiolarians identified include common Lithocyclia ocellus and Thyrocyrtis rhizodon, with Sethochytris triconiscus (PI. 4, Fig. 5) and its ancestor, $S$. babylonis group, Eusyringium fistuligerum, Podocyrtis trachodes, Podocyrtis chalara (Pl. 4, Fig. 4), Thyrsocyrtis tricantha, and rare Theocotylissa ficus and Tristylospyris triceros. Rare specimens closely resemble Podocyrtis mitra, the ancestor of P. chalara (PI. 4, Fig. 3). The co-occurrence of $T$. triceros, $P$. chalara, $P$. trachodes, and $P$. mitra suggest that the lower part of the Podocyrtis chalara Zone, approximately 42-42.2 Ma, according to the correlation of Berggren et al. (1985). Late Eocene radiolarian Zones Podocyrtis goetheana and Thyrsocyrtis bromia (= Calocyclas bandyca Zone, "Carpocanistrum" azyx Zone, and Cryptroprora ornata Zone of Saunders et al., 1985) are not found, indicating a hiatus, although part of this time gap may be represented by the interval in Core $124-770 \mathrm{~B}-15 \mathrm{R}$ that is barren of radiolarians. The occurrence of a hiatus in this interval is supported by nannofossils (Shyu and Müller, this volume) and foraminifers (Nederbragt, this volume). Basaltic basement at Site 770 is late middle Eocene or older, as with Site 767.

\section{DISCUSSION}

Pelagic clays and marls began accumulating at Sites 767 and 770 in the Celebes Sea after formation of basaltic crust in the middle Eocene. Pelagic sedimentation continued until early Miocene time, when sedimentation became strongly influenced by continentally derived material. Site 767 was below CCD during this entire interval, whereas Site 770 was near or above CCD from late middle Eocene through early Oligocene time.

Three Paleogene radiolarian biostratigraphic zones are identified in Celebes Sea sediments. However, biostratigraphic datums are not well defined, due to variable preservation, poor sediment recovery, and apparent hiatuses. Radiolarians within Paleogene pelagic clays do allow reasonably good biostratigraphic correlation between the two sites (Fig. $3)$. Although Sites 767 and 770 are presently separated by only about $23 \mathrm{nmi}(43 \mathrm{~km})$, the radiolarian assemblages are dis-

\footnotetext{
${ }^{3}$ This depth represents the level in the sampling portion of the core. The identical level in the archival half of the core is at $124-770 \mathrm{~B}-16 \mathrm{R}-3,48 \mathrm{~cm}$. Figure 2 shows the level in the archive core, $5 \mathrm{~cm}$ below that in the sampling half.
}

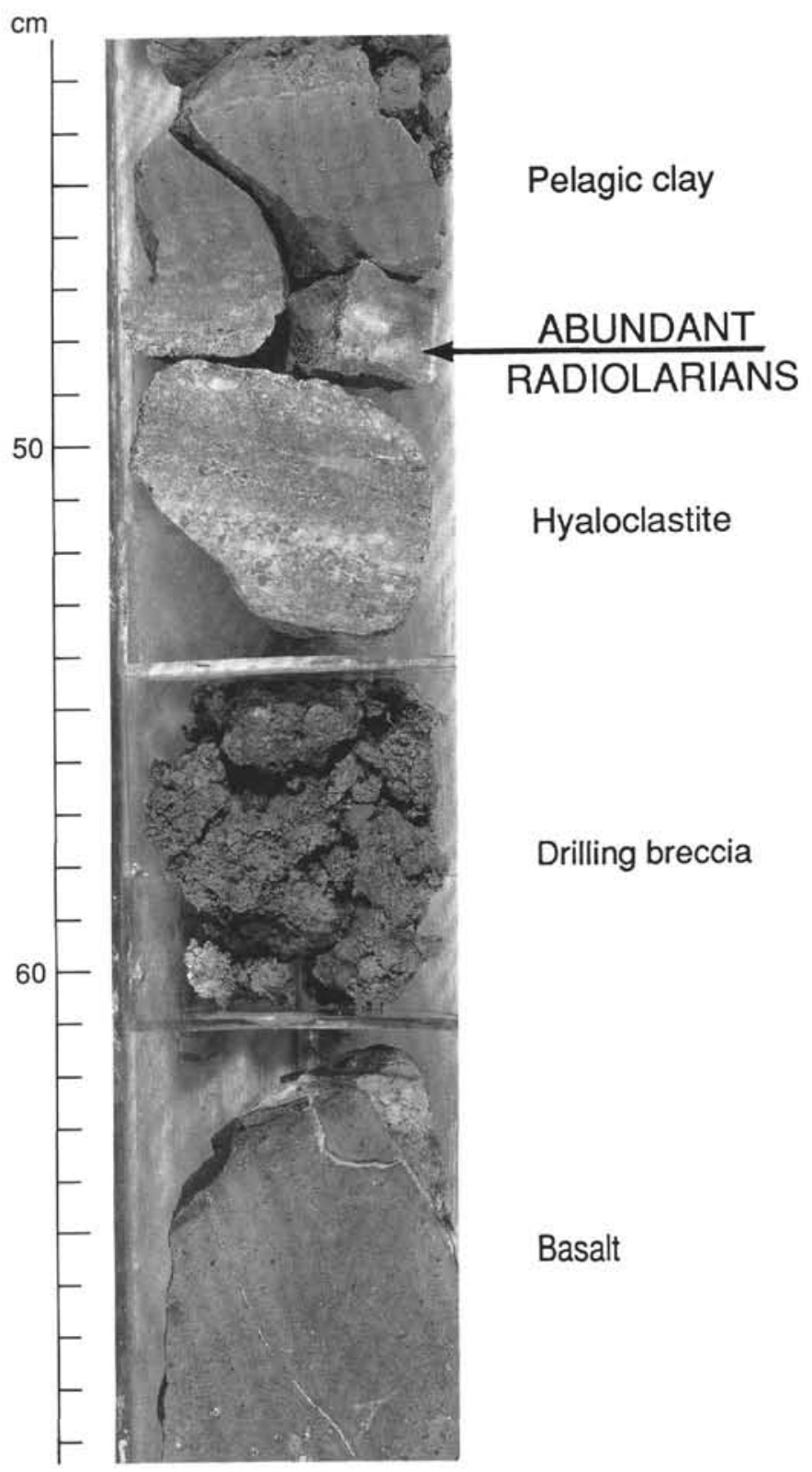

Figure 2. Core photograph of Section 124-770B-16R-3, showing contact between basalt and upper middle Eocene pelagic clay. Radiolarians are preserved only in a $1-\mathrm{cm}$ layer that overlies a thin hyaloclastite unit.

tinctly different with regard to state of preservation of the fossils. Site 767 radiolarians are rather poorly preserved throughout, whereas certain upper Oligocene sediments at Site 770 are quite well preserved.

During the Oligocene, radiolarians of the genus Dorcadospyris (including Tristylospyris) proliferated. The transition of Tristylospyris triceros to Dorcadospyris ateuchus occurs over a long stratigraphic range, and intermediate forms between $T$. triceros, D. ateuchus, D. circulus, and others are very common. A broad concept was used in the identification of Tristylospyris triceros because T. triceros (sensu stricto) is, in actuality, not a predominant component of the assemblage.

Drill sites in the Philippine Basin, from DSDP Leg 31, particularly Site 292, contain Paleogene radiolarian-bearing sediments that provide an excellent opportunity for compari- 

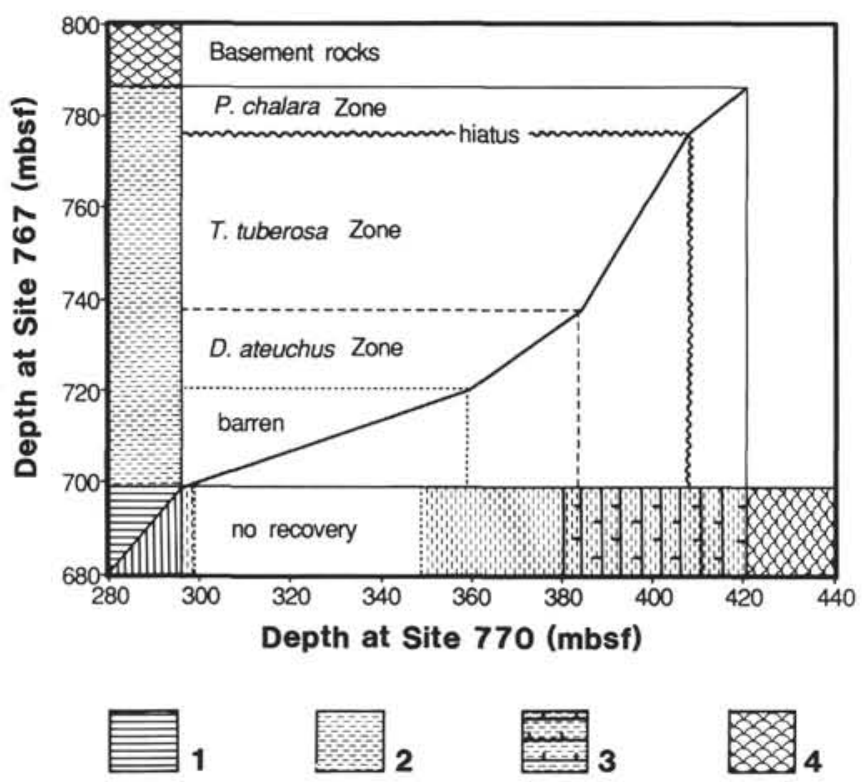

Figure 3. Correlation of Paleogene claystones of Sites 767 and 770 , with radiolarian zones and major hiatus identified. Key to lithologies: (1) green hemipelagic clay, (2) brown pelagic clay, (3) nannofossil marl, (4) pillow basalt.

son of the early history of these basins. In general, radiolarian preservation is good in Site 292 sediments (Ling, 1975). The $D$. ateuchus and $T$. tuberosa Zones are well represented and most of the radiolarians described by Ling from Site 292 are present in Sites 767 and 770 in the Celebes Sea. The most notable difference between Celebes and Philippine basin sediments is the apparent lack of strong dominance of abundant and diverse Dorcadospyris species in Philippine sediments, as is found in the Celebes Sea sediments. While diverse Dorcadospyris species are reported by Ling (1975), he does not indicate that they are abundant in his samples. In contrast, a nearly identical assemblage, strongly dominated by Dorcadospyris species, has been described from similar-aged sediments of tropical Atlantic Site 628, on the Little Bahama Bank (Palmer, 1988). The oceanographic significance of this phenomenon is unclear at this time.

A late Eocene hiatus or condensed section is suggested in Celebes Sea sites by the lack of radiolarian zones Podocyrtis goetheana and Thyrsocyrtis bromia $(=$ Calocyclas bandyca Zone, "Carpocanistrum" azyx Zone, and Cryptroprora ornata Zone). The age of sediments above basement in the Celebes Sea is lower $P$. chalara Zone, late middle Eocene in age. By contrast, Site 292 in the Philippine Basin contains nearly $40 \mathrm{~m}$ of late Eocene sediments with radiolarians of the T. bromia Zone (Ling, 1975). A major late Eocene hiatus is not evident in the Philippine Basin. Basement ages in the Philippine and Celebes Basins suggest that they may have formed from related spreading centers, but the age of Celebes Sea crust may be more than 6 Ma older than Philippine Sea crust.

\section{SYSTEMATICS}

Artophormis barbadensis (Ehrenberg)

Calocyclas barbabensis Ehrenberg, 1873, p. 217; 1875, Pl. 18, Fig. 8.

Artophormis barbadensis (Ehrenberg), Riedel and Sanfilippo, 1970, p. 532; Riedel and Sanfilippo, 1971, Pl. 3B, Fig. 9.

Artophormis gracilis Riedel

Artophormis gracilis Riedel, 1959, p. 300, Pl. 2, Figs. 12, 13; Moore, 1971, Pl. 5, Figs. 10, 11; Sanfilippo et al., 1973, PI. 4, Fig. 4.
Cyclampterium pegetrum Sanfilippo and Riedel

[Pl. 2, Fig. 8] Cyclampterium (?) pegetrum Sanfilippo and Riedel, 1970, p. 456, PI. 2, Figs. 8-10.

Cyclampterium pegetrum Riedel and Sanfilippo, 1978, p. 68, Pl. 4, Fig. 16.

Diartus hughesi (Campbell and Clark)

Ommatocampe hughese Campbell and Clark, 1944, p. 23, Pl. 3. Fig. 12.

Ommatartus hughesi (Campbell and Clark), Riedel and Sanfilippo, 1970 , p. 521.

Diartus hughesi (Campbell and Clark), Sanfilippo and Riedel, 1980, p. 1010; Riedel and Sanfilippo, 1971, Pl. 1C, Figs. 17, 18; Johnson, 1974, Pl. 7, Figs. 8-10; Holdsworth, 1975, Pl. 1, Figs. 3-5.

Didymocyris antepenultima (Riedel and Sanfilippo)

Ommatartus antepenultimus Riedel and Sanfilippo, 1970, p. 521, PI. 14, Fig. 4.

Didymocyrtis antepenultima (Riedel and Sanfilippo), Sanfilippo and Riedel, 1980, p. 1010; Westberg and Riedel, 1978, Pl. 2, Figs. 4,5 .

Didymocyrtis penultima (Riedel)

Panarium penultimum Riedel, 1957a, p. 76, Pl. 1, Fig. 1

Ommatartus penultimus (Riedel), Westberg and Riedel, 1978, p. 22.

Didymocyrtis penultima (Riedel), Sanfilippo and Riedel, 1980, p. 2, Figs. 6-8.

Dorcadospyris ateuchus (Ehrenberg) [PI. 4, Fig. 1] Ceratospyris ateuchus Ehrenberg, 1873, p. 218; 1875, Pl. 21, Fig. 4.

Dorcadospyris ateuchus (Ehrenberg), Riedel and Sanfilippo, 1970, p. 523; Moore, 1971, PI. 8, Figs. 1, 2; Ling, 1975, Pl. 5, Figs. 3-6.

Dorcadospyris circulus (Haeckel)

[Pl. 3, Figs. 2, 3]

Gamospyris circulus Haeckel, 1887, p. 1042, Pl. 85, Fig. 6.

Dorcadospyris circulus (Haeckel), Moore, 1971, p. 739, PI. 8, Figs. 3-5; Palmer, 1988, p. 116, Pl. 2, Fig. 4.

Dorcadospyris riedeli Moore

[PI. 3, Fig. 6] Dorcadospyris riedeli, Moore, 1971, p. 739, PI. 9, Figs. 1-3; Ling, 1975 , p. 726 , Pl. 6, Fig. 7.

Dorcadospyris simplex (Riedel)

Brachiospyris simplex Riedel, 1959, p. 293, Pl. 1, Fig 10.

Dorcadospyris simplex (Riedel), Riedel and Sanfilippo, 1970, Pl. 15, Fig. 6.

Dorcadospyris spp.

[PI. 3, Fig. 1, 2]

Comments: Forms included in this category include those too poorly preserved for specific identification and well-preserved transitional or undescribed varieties. The most common variety included in this category appears transitional between $D$. circulus and $T$. triceros.

Eusyringium fistuligerum (Ehrenberg)

Eucyrtidium fistuligerum Ehrenberg, 1873, p. 229; 1875, Pl. 9, Fig. 3.

Eusyringium fistuligerum (Ehrenberg), Riedel and Sanfilippo, 1970, p. 527 , Pl. $8,9$.

Lithocyclia angusta (Riedel)

[PI. 2, Figs. 6, 8] Trigonactura angusta Riedel, 1959, p. 292, PI. 1, Fig. 6.

Lithocyclia angustum (Riedel), Riedel and Sanfilippo, 1970, p. 522, Pl. 13, Figs. 1, 2.

Lithocyclia angusta (Riedel), Sanfilippo, Westberg-Smith and Riedel, 1985, p. 653, Fig. 7 (3 a-c).

Lithocyclia ocellus (Ehrenberg) group

Lithocyclia ocellus Ehrenberg, 1854, Pl. 36, Fig. 30; 1873, p. 240. Lithocyclia ocellus Riedel and Sanfilippo, 1970, p. 522, PI. 5, Figs. $1,2$.

Lychnocanoma trifolium (Riedel and Sanfilippo) [PI. 1, Fig. 1] Lychnocanium trifolium Riedel and Sanfilippo, 1971, p. 1595, PI. 3B, Fig. 12, PI. 8, Figs. 2, 3.

Lychnocanoma trifolium (Riedel and Sanfilippo), (implied) in Sanfilippo et al., 1973, p. 221; Ling, 1975, Pl. 10, Fig. 12.

Lychnocanoma sp. A

[PI. 1, Figs. 2-4, 6-8]

Comments: Overall dimensions, shape, and position of the feet, cephalis, and apical spine are all comparable to Lychnocanoma trifolium (s.s.). Unlike Lychnocanoma trifolium, most specimens have numerous open pores on the thorax; however, the upper part of 
the thorax tends to contain a predominance of closed pores. Many specimens show a rudimentary grouping of three larger open pores on the upper part of the thorax (Pl. 1, Fig. 2), which further suggests affinity with $L$. trifolium. This is a delicate species and although many specimens have been seen, nearly all are at least partially broken (PI. 1, Figs. 2-4). Although the biostratigraphic range of this radiolarian is unknown, it co-occurs with L. trifolium in Leg 124 material.

Podocyrtis (Lampterium) chalara Riedel and Sanfilippo[PI. 4, Fig. 3] Podocyrtis (Lampterium) chalara Riedel and Sanfilippo, 1970, p. 535, Pl. 12, Figs. 2, 3; Riedel and Sanfilippo, 1978, Fig. 3; Riedel and Sanfilippo, 1981, Fig. 12-7, nos. 5-6, Fig. 12-8, nos. 9-12.

Podocyrtis (Lampterium) mitra Ehrenberg Podocyrtis mitra Ehrenberg, 1854, Pl. 36, Fig. B20 Riedel and Sanfilippo, 1978, Fig. 3.

Podocyrtis (Lampterium) trachodes Riedel and Sanfilippo Podocyrtis (Lampterium) trachodes Riedel and Sanfilippo, 1970, p. 535, Pl. 11, Fig. 7, Pl. 12, Fig. 1.

Pterocanium audax (Riedel) Lychnodictyum audax Riedel, 1953, p. 810-811, Pl. 85, Fig. 9; Nigrini and Lombardi, 1985, p. N123-N124, Pl. 25, Fig. 1. Pterocanium audax (Riedel) Lazarus, Scherer and Prothero, 1985, p. 202-204, Fig. 19, nos. 1-5.

Pterocanium charybdeum trilobum (Haeckel) Dictyopodium trilobum Haeckel, 1860, p. 839.

Pterocanium trilobum Hays, 1965, p. 177-178, Pl. 3, Fig. 10. Nigrini, 1967, p. 71-72, Pl. 7, Fig. 3a. Nigrini and Lombardi, 1985, p. N127-N128, Pl. 25, Fig. 3.

Pterocanium charybdeum trilobum (Haeckel) Lazarus, Scherer and Prothero, 1985, p. 195-196, Fig. 10, nos. 1-4.

Pterocanium sp. B

[PI. 1, Fig. 5] Pterocanium audax? "small form" Lazarus, Scherer and Prothero, 1985 , p. $202-204$, Fig. 19 , no. 5.

Comments: This small, stout, large-pored radiolarian possesses a simple apical horn and short feet. According to Lazarus, Scherer, and Prothero (1985) it may be a small form of $P$. audax.

Pterocanium (?) sp. A

[PI. 1, Figs. 9-11]

Comments: This theoperid has large pores, a poreless cephalis with a short conical horn and long, strongly bladed feet. The feet may be simple or may posess spines suggestive of an attached abdomen (not preserved in any specimens studied). The feet may be straight or outwardly flaired and occasionally appear twisted.

Sethochytris babylonis group (Clark and Campbell)

Dictyophimus babylonis Clark and Campbell, 1942, p. 67, Pl. 9, Figs. 32, 36.

Lychnocanium lucerna Ehrenberg, 1847, Fig. 5, 1854, Pl. 36, Fig. 6, 1873, p. 244.

Sethochytris babylonis (Clark and Campbell) group, Riedel and Sanfilippo, Pl. 9, Figs. 1-3; Moore, 1971, p. 755, Pl. 3, Figs. 9, 10.

Sethochytris triconiscus Haeckel

[PI. 4, Fig. 5, 6] Sethochytris triconiscus Haeckel, 1887, p. 1239, Pl. 57, Fig. 13; Riedel and Sanfilippo, 1970, p. 528, PI. 9, Figs. 5, 6.

Stichocorys peregrina (Riedel)

Eucyrtidium elongatum peregrinum Riedel, 1953, p. 812, Pl. 85, Fig. 2.

Stichocorys peregrina (Riedel) Riedel and Sanfilippo, 1970, p. 451, Pl. 1, Fig. 10; Westberg and Riedel, 1978, P. 22, Pl. 3, Figs. 6-9. Theocotylissa ficus (Ehrenberg)

Eucyrtidium ficus Ehrenberg, 1873, p. 228; 1875, Pl. 11, Fig. 19. Theocotylissa ficus (Ehrenberg), Sanfilippo and Riedel, 1982, p. 180.

Theocyrtis annosa (Riedel)

[PI. 2, Figs 1-3]

Phormocyrtis annosa Riedel, 1959, p. 295, Pl. 2, Fig. 7.

Theocyrtis annosa (Riedel), Riedel and Sanfilippo, 1970, p. 535; Riedel and Sanfilippo, 1971, p. 1598, Pl. 2H, Fig. 4, PI. 3D, Figs. 12, 13; Moore, 1971, p. 743, Pl. 7, Figs. 6, 7.

Comments: Specimens identified as T. annosa tended to be somewhat smaller than the original description would suggest. Poor preservation makes identification questionable in many specimens. Some specimens identified as $T$. annosa may be an early Oligocene Calocycletta sp. (sensu Ling, 1985, p. 731, Pl. 12, Figs. 13, 14).

Theocyrtis tuberosa Riedel

[PI. 2, Figs. 4, 5] Theocyrtis tuberosa Riedel, 1959, p. 298, Pl. 2, Figs. 10, 11; Riedel and Sanfilippo, 1970, PI. 13, Figs. 8-10; 1971, PI, 3D, Figs. 14-18; 1978a, PI. 1, Figs. 10, 11.

Thyrsocyrtis rhizodon Ehrenberg

Thyrsocyrtis rhizodon Ehrenberg, 1873, p. 262; 1875, p. 94, PI. 12, Fig. 1; Sanfilippo and Riedel, 1982, p. 173, PI. 1, Figs. 14-16, Pl. 3, Figs. 12-17.

Thyrsocyrtis tricantha Ehrenberg

Podocyrtis triacantha Ehrenberg, 1873, p. 254; 1875, PI. 13, Fig. 4.

Thyrsocyrtis tricantha (Ehrenberg) Riedel and Sanfilippo, 1970; Sanfilippo and Riedel, 1982, p. 176, PI. 1, Figs. 8-10, Pl. 3, Figs. 3, 4.

Tristylospyris triceros (Ehrenberg)

[PI. 4, Fig. 2]

Ceratospyris triceros Ehrenberg, 1873, p. 220; 1875, Pl. 21, Fig. 5.

Tristylospyris triceros (Ehrenberg), Haeckel, 1887, p. 1033, Moore, 1971, Pl. 6, Figs. 1-3; Ling, 1975, Pl. 6, Figs. 1-6.

\section{ACKNOWLEDGMENTS}

I thank all of the scientific and support crew of the JOIDES Resolution, and particularly Carla Müller and the Co-chiefs, for their encouragement, as I struggled to learn the subtleties of radiolarian biostratigraphy (on poorly preserved material) as core came on deck. I would also like to acknowledge A. Sanfilippo, M. Westberg-Smith, and W. Riedel for their excellent compilation of Cenozoic radiolarian biostratigraphy in the Plankton Stratigraphy volume (1985). This volume was my guiding light as Co-chiefs called out "Well, what age is it?" I also thank A. Palmer and H. Y. Ling for helpful comments in review. This work was funded in part by the Ocean Drilling Program and USSAC.

\section{REFERENCES}

Berggren, W. A., Kent, D. V., Flynn, J. J., and Van Couvering, J. A., 1985. Cenozoic geochronology. Geol. Soc. Am. Bull., 96:14071418.

Campbell, A. S., and Clark, B. L., 1944. Miocene radiolarian faunas from Southern California. Spec. Pap. - Geol. Soc. Am., 51:1-76.

Ehrenberg, C. G., 1854. Mikrogeologie, das Erden und Felsen schaffende Wirken des unsichtbar kleinen selbständigen Lebens auf der Erde: Leipzig (Leopold Voss).

1873. Grössere Felsproben des Polycystinen-Mergels von Barbados mit weiteren Erlaüterungen. K. Preuss. Akad. Wiss. Berlin, Monatsberichte, 213-263.

1875. Fortsetzung der mikrogeologischen Studien als Gesammt-Übersicht der mikroskopischen Paläontologie gleichartig analysirter Gebirgsarten der Erde, mit spezieller Rücksicht auf den Polycystinen-Mergel von Barbados. Abh. K. Akad. Wiss. Berlin, 1-225.

Haeckel, E., 1887. Report on the Radiolaria collected by H.M.S. Challenger during the years 1873-1876. Rep. Sci. Results of the Voyage of the H.M.S. Challenger. Zoology, 18.

Hays, J. D., 1965. Radiolaria and late Tertiary and Quaternary history of Antarctic seas. In Llano, G. A. (Ed.), Biology of the Antarctic Seas II: Antarct. Res. Ser., 5:125-184.

Holdsworth, B. K., 1975. Cenozoic radiolaria biostratigraphy: Leg 30: tropical and equatorial Pacific. In Andrews, J. E., Packham, G., et al., Init. Repts. DSDP, 30: Washington (U.S. Govt. Printing Office), 499-537.

Johnson, D. A., 1974. Radiolaria from the eastern Indian Ocean, DSDP Leg 22. In von der Borch, C. C., Sclater, J. G., et al., Init. Repts. DSDP., 22: Washington (U.S. Govt. Printing Office), 521-575.

Lazarus, D. B., Scherer, R., and Prothero, D., 1985. Evolution of the radiolarian species-complex Pterocanium: a preliminary report. $J$. Paleontol., 59:183-220.

Ling, H. Y., 1975. Radiolaria: Leg 31 of the Deep Sea Drilling Project. In Karig, D. E., Ingle, J. C., Jr., et al., Init. Repts. DSDP, 31: Washington (U.S. Govt. Printing Office), 703-761. 
Moore, T., 1971. Radiolaria. In Tracey, J. I., Jr., Sutton, G. H., et al., Init. Repts. DSDP, 8: Washington (U.S. Govt. Printing Office), 727-775.

Nigrini, C., 1967. Radiolaria in pelagic sediments from the Indian and Atlantic Oceans. Bull. Scripps Inst. Oceanogr., 11:1-125.

Nigrini, C., and Lombardi, G., 1984. A Guide to Miocene Radiolaria. Spec. Publ. Cushman Found. Foraminiferal Res., No. 22.

Palmer, A. A., 1988. Cenozoic radiolarians from Ocean Drilling Program Leg 101, Bahamas (Sites 627 and 628) and surrounding region. In Austin, J. A., Jr., Schlager, W., et al., Proc. ODP, Sci. Results, 101: College Station, TX (Ocean Drilling Program), 105-116.

Riedel, W. R., 1953. Mesozoic and late Tertiary Radiolaria of Rotti. $J$. Paleontol., 27:805-813.

1957. Radiolaria: a preliminary stratigraphy. Rep. Swed.

Deep-Sea Exped., 1947-1948, 6:59-96.

1959. Oligocene and Lower Miocene Radiolaria in tropical Pacific sediments. Micropaleontology, 5:285-302.

Riedel, W. R., and Sanfilippo, A., 1970. Radiolaria, Leg 4, Deep Sea Drilling Project. In Bader, R. G., Gerard, R. D., et al., Init. Repts. DSDP, 4: Washington (U.S. Govt. Printing Office), 503-575.

1971. Cenozoic Radiolaria from the western tropical Pacific, Leg 7. In Winterer, E. L., Riedel, W. R., et al., Init. Repts. DSDP 7 (Pt. 2): Washington (U.S. Govt. Printing Office), 15291672.
1978. Stratigraphy and evolution of tropical Cenozoic radiolarians. Micropaleontology, 24:61-96.

A., 1981. Evolution and diversity of form in Radiolaria. In Simpson, T. L., and Volcani, D. E. (Eds.), Silicon and Siliceous Structures in Biological Systems: New York (Springer-Verlag), 323-346.

Sanfilippo, A., Burckle, L. H., Martini, E., and Riedel, W. R., 1973. Radiolarians, diatoms, silicoflagellates and calcareous nannofossils in the Mediterranean Neogene. Micropaleontology, 19:209-234.

Sanfilippo, A., and Riedel, W. R., 1970. Post-Eocene "closed" theoperid radiolarians. Micropaleontology, 16:446-462.

, 1980. A revised generic and suprageneric classification of the Artiscins (Radiolaria). J. Paleontol., 54:1008-1011.

1982. Revision of the radiolarian genera Theocotyle, Theocotylissa, and Thyrsocyrtis. Micropaleontology, 28:170-188.

Sanfilippo, A., Westberg-Smith, M. J., and Riedel, W. R., 1985. Cenozoic radiolaria. In Bolli, H. M., Saunders, J. B., and PerchNielsen, K. (Eds.), Plankton Stratigraphy: Cambridge (Cambridge Univ. Press), 631-712.

Westberg, M. J., and Riedel, W. R., 1978. Accuracy of radiolarian correlations in the Pacific Miocene. Micropaleontology, 24:1-23.

Date of initial receipt: 12 July 1990

Date of acceptance: 5 October 1990

Ms 124B-133 

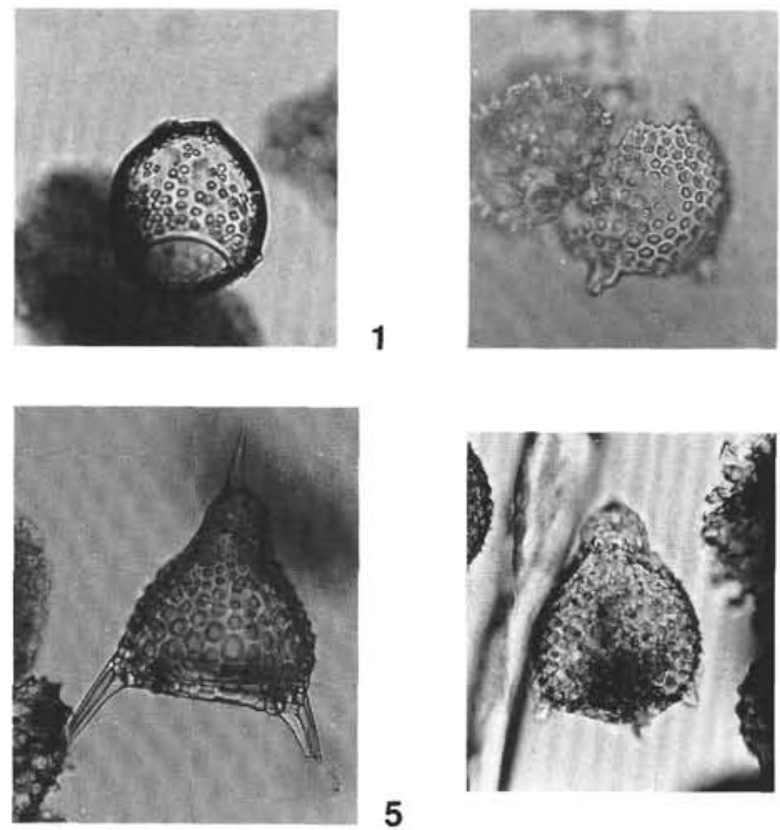

5

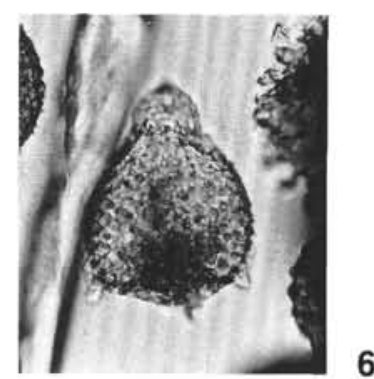

6

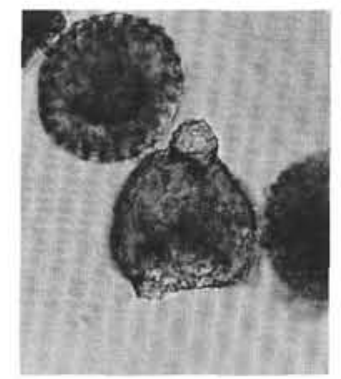

7

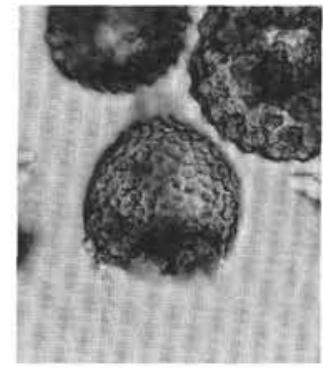

8

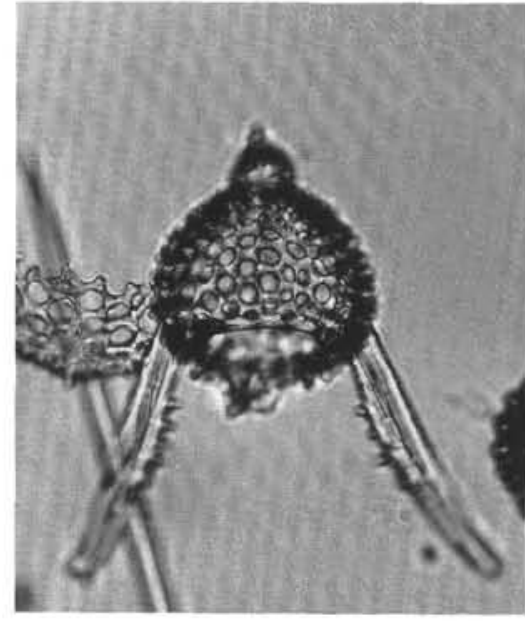

9

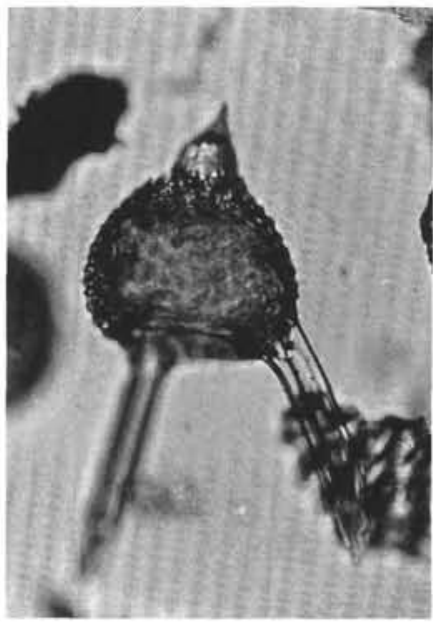

10

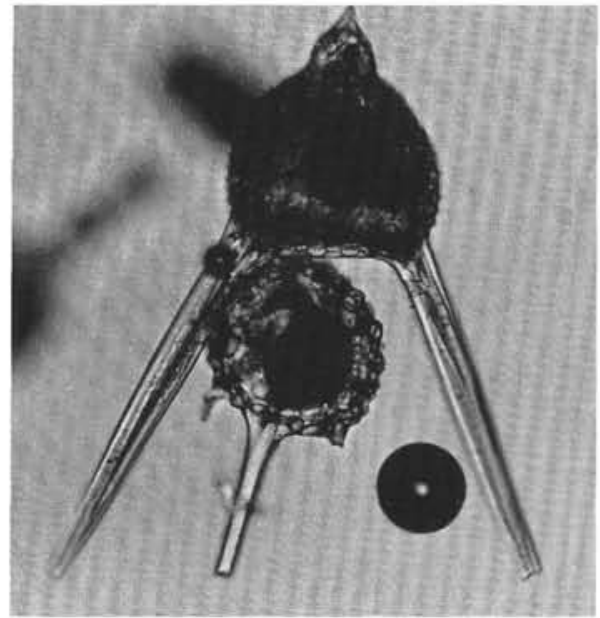

11

Plate 1. Magnification $200 \times$. 1. Lychnocanoma trifolium. Sample 124-770C-1R-1, 39-41 cm. 2-4. Lychnocanoma sp. A. Sample 124-770B-10R-3, 125-130 cm. 5. Pterocanium sp. B. Sample 124-770B-6R-1, 6-7 cm. 6-8. Lychnocanoma sp. A. Sample 124-767B-77X-2, 23-25 cm. 9-11. Pterocanium(?) sp. A. Sample 124-770C-1R-1, 39-41 cm. 

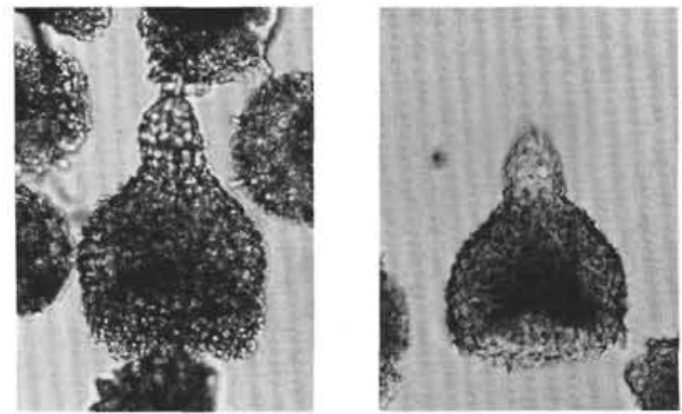

1

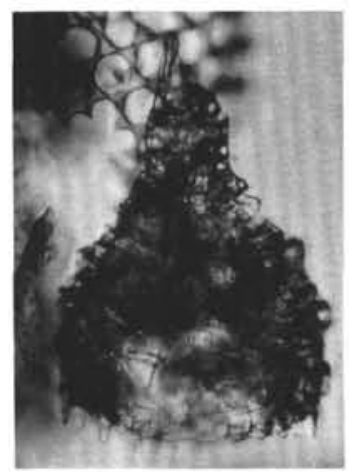

5
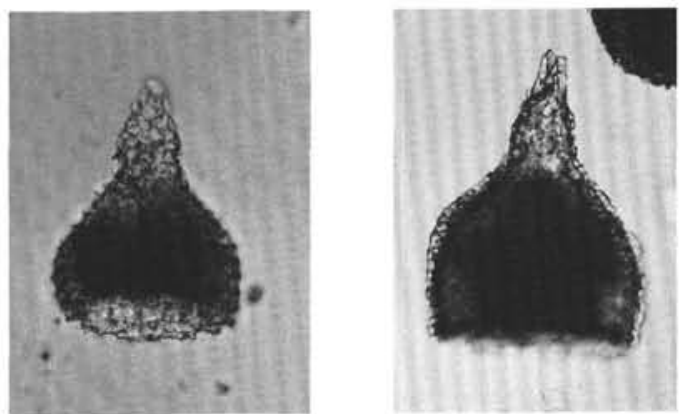

3
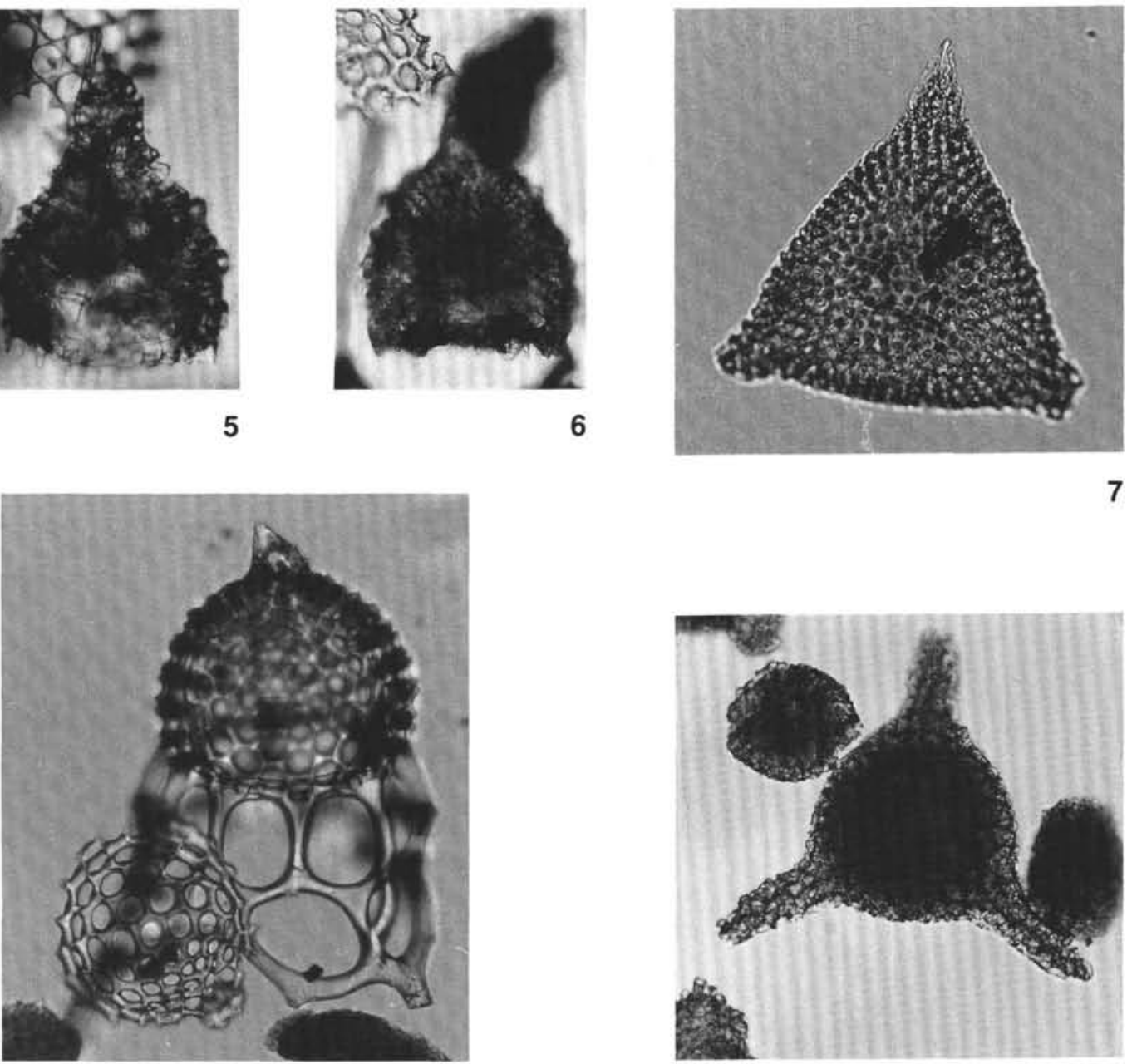

8

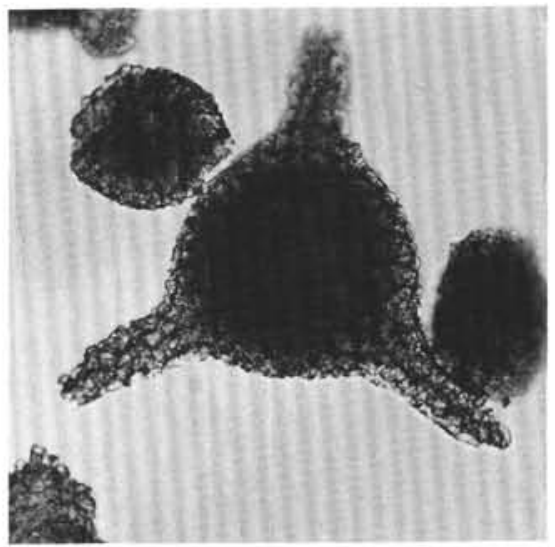

Plate 2. Magnification 200×. 1-3. Theocyrtis annosa. Sample 124-767C-6R-5, 39-42 cm. 4. Theocyrtis tuberosa. Sample 124-767B-78R, CC. 5, 6. T. tuberosa. Sample 124-770C-1R-1, 39-42 cm. 7. Lithocyclia angusta, late form (D. ateuchus Zone). Sample 124-767B-76R, CC. 8. Cyclampterium pegetrum. Sample 124-770B-11R, CC. 9. Lithocyclia angusta, typical early form (T. tuberosa Zone). Sample 124-767C-9R-1, 90-92 cm. 
R. P. SCHERER
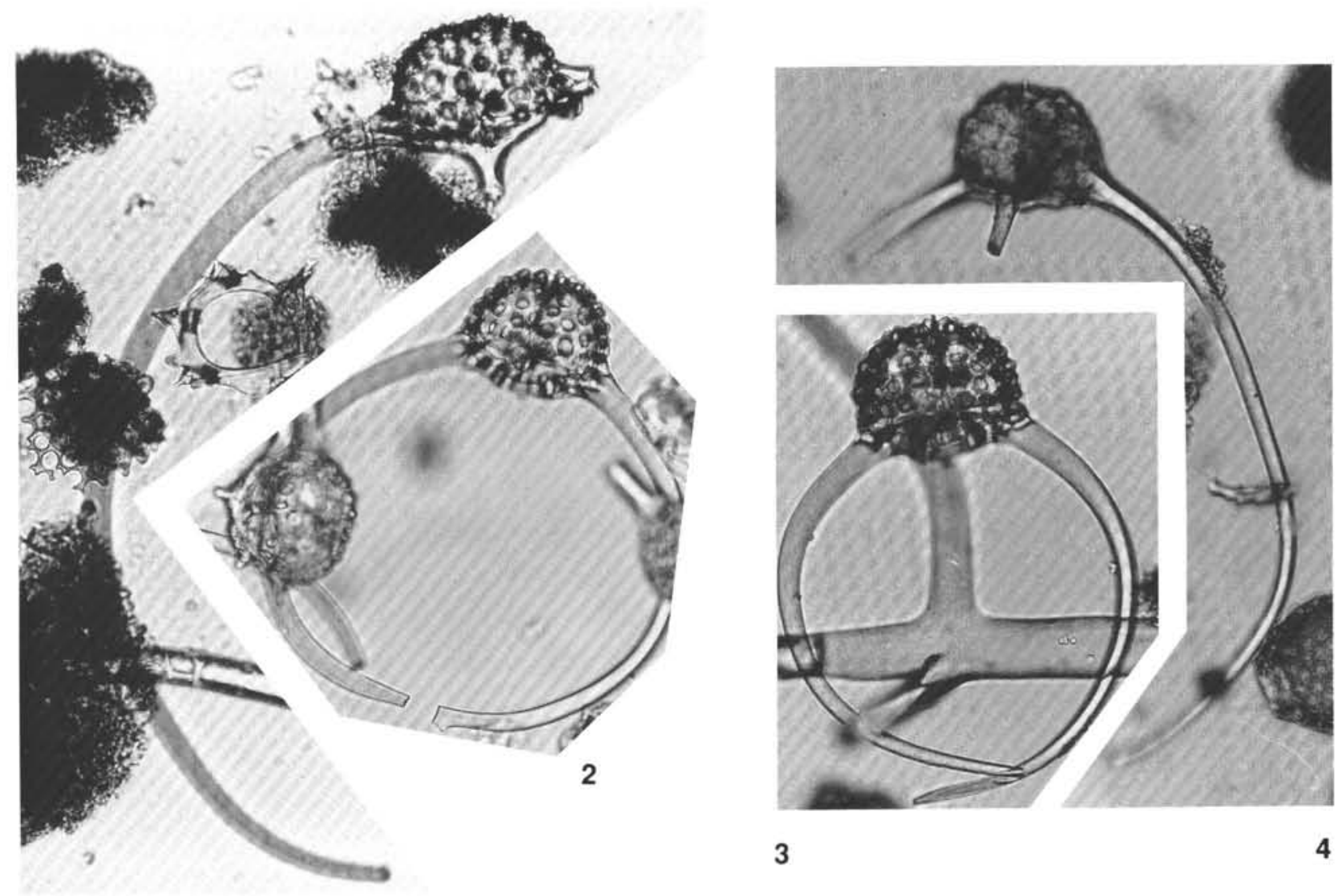

1
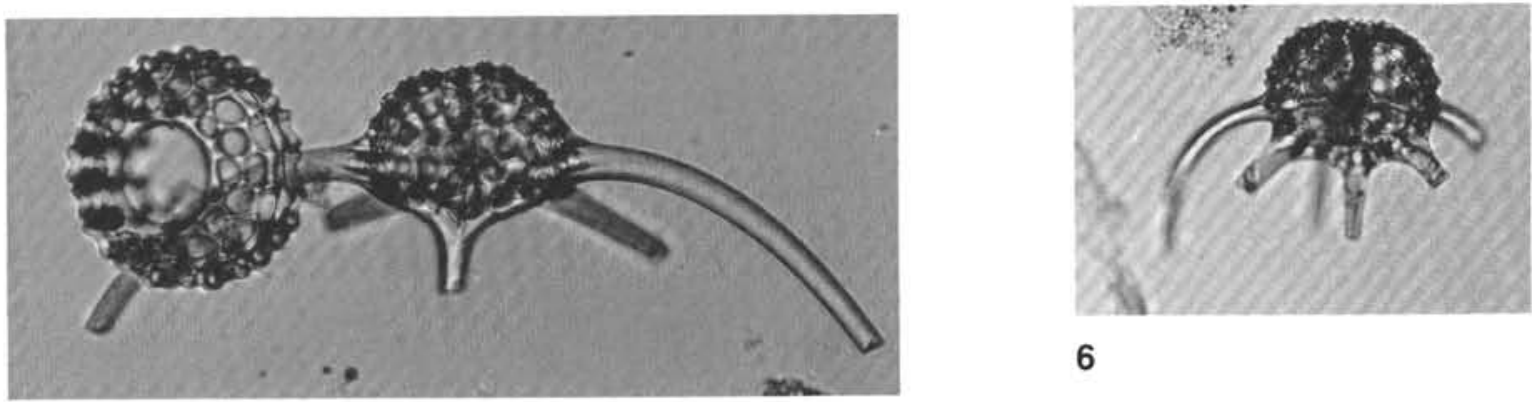

6

5

Plate 3. Magnification $200 \times$. 1, 4, 5. Dorcadospyris spp. Sample 124-770B-11R, CC. 2, 3. Dorcadospyris circulus. Sample 124-770B-12R, CC. 6. Dorcadospyris riedeli. Sample 124-770C-IR-1, 39-41 cm. 

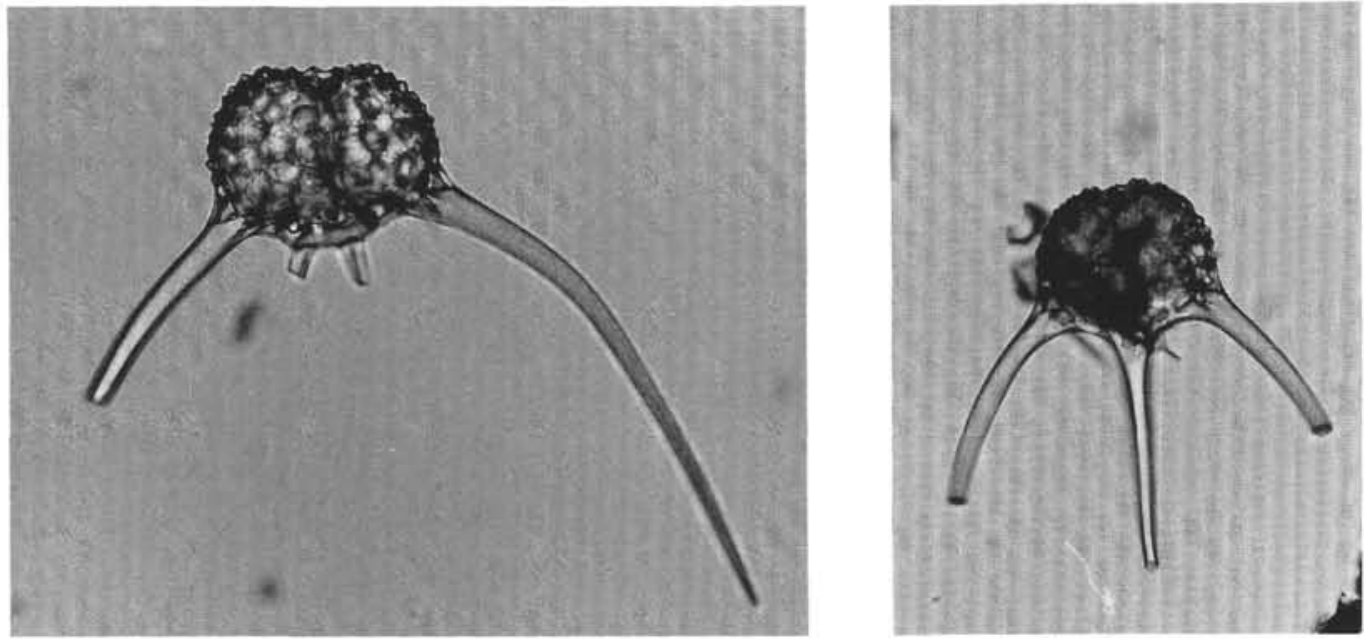

1
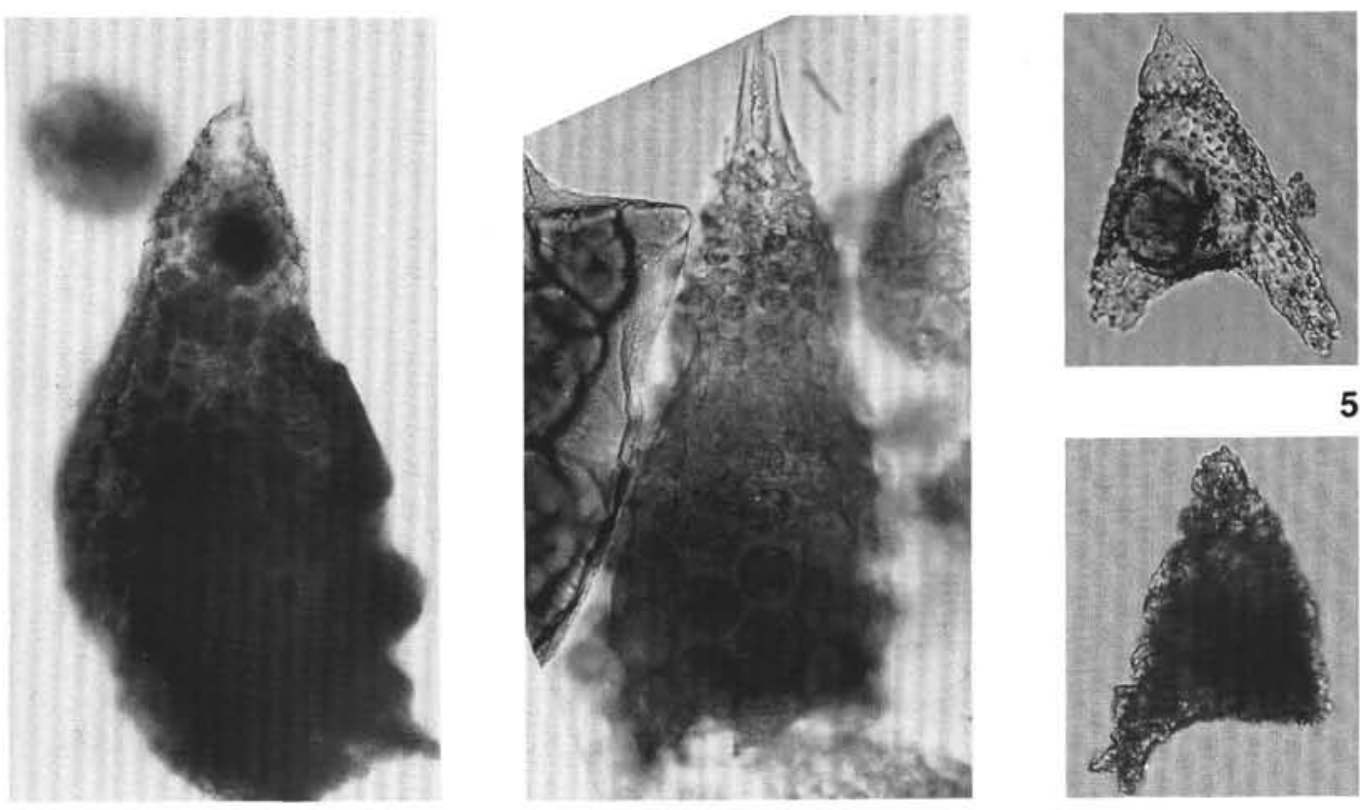

6

Plate 4. Magnification 200×. 1. Dorcadospyris ateuchus. Sample 124-770B-11R, CC. 2. Tristylospyris triceros. Sample 124-770C-1R-1, 39-41 cm. 3. Podocyrtis mitra. Sample 124-770B-16R-3, $42-43 \mathrm{~cm}$. 4. Podocyrtis chalara. Sample 124-770B-16R-3, 42-43 cm. 5. Sethochytris triconiscus. Sample 124-770B-16R-3, 42-43 cm. 6. Sethochytris triconiscus. Very poor preservation. Sample 124-767C-12R-2, 35-37 cm. 